\title{
Research on Manager's Overconfidence and Enterprise Financial Dilemma: A Case Analysis Based on LeEco company
}

\author{
Meijuan Zou* \\ School of Economics and Management \\ Jiangxi University of Science and Technology \\ Ganzhou,341000,China \\ 1197035594@qq.com
}

\author{
Wenwen $\mathrm{Wu}$ \\ School of Economics and Management, associate professor \\ Jiangxi University of Science and Technology \\ Ganzhou, 341000,China
}

\begin{abstract}
Most business managers will overestimate their abilities, have greater confidence in the business situation of enterprises, easily overestimate investment returns and underestimate the risks in operation. Such overconfidence will easily lead to radical financial decisions and increase the probability of enterprises falling into financial difficulties. This paper takes the former Star Enterprise LeEco Company as the research object. From the perspective of managers' overconfidence, it takes managers' investment and financing behavior as intermediary variable to explore how managers' overconfidence affects and causes enterprises to fall into financial distress. It is found that managers' overconfidence will make enterprises tend to over-investment and prefer debt financing, and then increase the financial risk of enterprises, and make enterprises fall into financial difficulties.
\end{abstract}

Keywords-LeEco; Overconfidence of managers; Financial difficulties

\section{INTRODUCTION}

Since roll [1] pioneered the "arrogance hypothesis" and first introduced the concept of managerial overconfidence into financial research, more and more scholars have analyzed the strategic management and decision-making behavior of enterprises from the perspective of overconfidence, and confirmed that many failure cases of enterprises are related to managerial overconfidence. However, most of the existing literatures take listed companies as samples to explore the relationship between managerial overconfidence and financial distress, but seldom analyze the mechanism and impact path between them. The case study method is used to solve the problem of "how to influence" and "why to influence". From the former A-share star enterprises to the present "performance slump" is a sigh. The failure lessons of its falling into the altar and heading for the predicament should arouse our attention and reflection. Based on this, this paper analyses the causes of the financial distress from the perspective of psychological deviation of the over-confidence of the managers of LeEco company , and puts forward corresponding countermeasures, which will help managers to better understand themselves and avoid the negative impact of their over-confidence on the company's strategic decision-making.

\section{CASE BACKGROUND INTRODUCTION OF LEECO COMPANY}

LeEco company, was listed in 2010. It was the first IPO listed company in the world and the only online video company listed in A shares in China at that time. Since its establishment, LeEco company has grown rapidly, devoted to creating a new vertical industrial ecosystem of "platform + content + terminal + application", and has made remarkable achievements in the fields of video, content and intelligent terminals. The breakdown of the capital chain in November 2016 triggered a sharp drop in LeEco company's share price, which fell $10.42 \%$ in three days, and the market value evaporated by about 9.1 billion yuan. Subsequently, the financial situation continued to deteriorate, the company was repeatedly suspended stock trading, and on May 13, 2019 issued a suspension of listing announcement.

\section{OVERCONFIDENCE OF LEECO COMPANY'S MANAGERS}

\section{A. Overconfidence Performance of Managers}

By the end of 2016, Yueting Jia, the founder of LeEco company, had more shares than the top ten shareholders of the company. He was also the chairman and general manager of the company. He had absolute voice over the strategic decision-making of the enterprise and was the main manager of the enterprise.

Yueting Jia's self-confidence and daring to subvert is well known.In order to realize the "closed ecological chain" model of LeEco, he has been subverting constantly. His business involves film and television, television, super car and so on The industry jokes that LeEco with its own strength involves almost all the areas that the Internet is eager to engage in. Moreover, Yueting Jia is extremely confident about the development prospects of various business areas, repeatedly claiming that the LeEco mobile phone is the most likely to surpass iPhone; that the LeEco car, which is regarded as a black hole of funds, is likely to be subversive while opposed by $99 \%$ of senior executives; and that even if there are technical barriers to the LeEco Super TV, it can create the future if it listens to its heart......However, capital demand, industry competition and technical barriers are all problems that need to 
be solved urgently. Yueting Jia's confidence in victory is enough to show that he is very confident.

\section{B. The Measurement of Overconfidence by Profit Forecasting}

How to measure managers' overconfidence effectively has always been the focus of domestic and foreign scholars, and some progress has been made in the selection of alternative indicators. Minggui $\mathrm{Yu}$ and Xinping $\mathrm{Xia}[2]$ pointed out that if the actual profit did not reach the forecast value, it means that managers have the characteristics of overconfidence. And some scholars used top three executive compensation as a proportion of total executive compensation to measure managers overconfidence level., they believed that the higher the executive salaries, the more likely they are to have a sense of superiority and inflation, and more likely to be overconfident. Other alternative indicators include Oliver's[3] consumer sentiment index method, Malmendier and Tate's[4] mainstream media evaluation method, Doukas and Petmezas[5] senior managers implement mergers and acquisitions frequency method, etc. Considering the convenience of data acquisition, this paper uses the annual earnings forecast deviation of listed companies to measure whether managers have overconfidence.

TABLE I. LEECO COMPANY'S PROFIT FORECAST UNIT: 10,000 RMB

\begin{tabular}{l|l|l|l|c}
\hline \multicolumn{1}{c|}{ year } & \multicolumn{1}{|c|}{$\mathbf{2 0 1 5}$} & $\mathbf{2 0 1 6}$ & \multicolumn{1}{c}{$\mathbf{2 0 1 7}$} & $\mathbf{2 0 1 8}$ \\
\hline Forecast profit cap & $\begin{array}{l}6,705 . \\
16\end{array}$ & $\begin{array}{l}77,358 . \\
67\end{array}$ & $\begin{array}{l}- \\
4\end{array}$ & \\
& $160,495.3$ & \\
\hline $\begin{array}{l}\text { Forecast earnings } \\
\text { floor }\end{array}$ & $\begin{array}{l}57,424 . \\
57\end{array}$ & $\begin{array}{l}63,032 . \\
99\end{array}$ & $\begin{array}{l}1,160,995.3 \\
4\end{array}$ & $-60,814.59$ \\
\hline Actual Profit & $57,302$. & $55,475$. & $1,387,804.4$ & \\
& 72 & 92 & 8 & $-409,561.94$ \\
\hline $\begin{array}{l}\text { Does Real Earnings } \\
\text { Over Performance }\end{array}$ & & & & \\
Forecast & No & No & No & No \\
\hline
\end{tabular}

Note: The value in the table refers to the net profit attributable to the owner of the company.

From the data in Table 1, we can see that in the four years from 2015 to 2018, the actual profit of LeEco has not reached the expected target, and the actual profit has not even reached the lower limit of the forecast profit. And the gap between actual earnings and bound limits of predicted earnings is also growing.

LeEco was exposed in 2016 that there is a tight capital chain. It has owed more than 10 billion RMB to its suppliers In 2017, its net profit fell sharply, resulting in its first loss since listing. With 2016 as the boundary, managers expect profits to climb sharply before LeEco falls into crisis, but they fail to achieve the expected profits. After the crisis, the management expected to lose little, trying to restore the reputation of LeEco and rebuild the confidence of investors, but the huge loss did not improve. According to the theory of overconfidence, LeEco predicts that the profit is higher than the actual profit again and again, and the absolute value of the difference between the two is increasing. It is not difficult to draw the conclusion that the managers of LeEco have overconfidence characteristics.

\section{LEECO COMPANY'S FINANCIAL DILEMMA}

Since its establishment, especially after putting forward the concept of setting up a LeEco ecosystem, the LeEco company has entered a period of continuous expansion and rapid development. After listing, the company maintained good and stable growth performance, once leading the network video industry. Until 2016, the company's capital chain broke down, and after that, annual profits, stock prices plummeted, and the company was unable to repay its maturing debts. All these signs indicate that the company is in financial distress. According to the academic research results, managers' overconfidence will accelerate the process of enterprises falling into financial distress. This section will analyze the financial distress of enterprises from two aspects of company's financial performance and market performance.

\section{A. Profits are deteriorating}

By sorting out the data of the annual report of LeEco in the past five years, we can get the following changes in the financial indicators of LeEco's operating performance. We can see thatLeEco has been losing heavily since 2016:

TABLE II. OPERATING PeRformance of LEECO 2014 TO 2018

\begin{tabular}{|c|c|c|c|c|}
\hline year & 2015 & 2016 & 2017 & 2018 \\
\hline $\begin{array}{l}\text { Operating income } \\
(10,000 \mathrm{RMB})\end{array}$ & $681,893.86$ & $\begin{array}{l}1,301,672.5 \\
1\end{array}$ & $\begin{array}{l}2,195,095.1 \\
4\end{array}$ & $\begin{array}{l}702,521.5 \\
8\end{array}$ \\
\hline $\begin{array}{l}\text { Increase rate of } \\
\text { business income }\end{array}$ & 1.89 & 0.91 & 0.69 & -0.68 \\
\hline $\begin{array}{l}\text { Operating } \\
\text { Cost }(10,000 \\
\text { RMB })\end{array}$ & $582,813.35$ & $\begin{array}{l}1,111,200.9 \\
1\end{array}$ & $\begin{array}{l}1,822,922.0 \\
6\end{array}$ & $\begin{array}{l}970,671.0 \\
0\end{array}$ \\
\hline $\begin{array}{l}\text { Net profit }(10,000 \\
\text { RMB })\end{array}$ & $12,879.66$ & $21,711.68$ & $-22,189.26$ & $\begin{array}{l}- \\
1,818,430 \\
.75\end{array}$ \\
\hline
\end{tabular}

According to the data in Table 2, LeEco's operating income has been rising steadily in 2016 and before, but its net profit in 2016 was negative for the first time. In 2017, it suffered a huge decline with a loss of $1818,430.75$ million RMB, which exceeded the total net profit in the previous four years and became the company with the largest loss in 2017 A-share listed companies. This shows that the company's profitability is declining under the impression of rising business income. At the same time, the company did not strengthen the control of operating costs, operating costs rose from 582,813.35 million RMB in 2014 to $1822,922.06$ million RMB in 2016. In addition, the company's return on net assets has declined sharply in recent years, reaching an all-time low of $-211.4 \%$ in 2017, reflecting that the company's current profitability has been in jeopardy, and in 2018 it did not turn a loss into a profit, with business revenue even falling by $78 \%$. The main reasons include the large-scale purchase of film and television copyright expenditure and the marketing strategy of sales of LeEco Super TV in the form of far lower than the industry average price, hardware not making money or low profit. All these have led to the poor net profit performance of LeEco, and the company's current profitability has been in jeopardy. 


\section{B. Debt servicing capacity continues to decline}

The solvency can reveal the financial risks of enterprises. Yu Sujing[6] believes that the excessive asset-liability ratio will increase the probability of companies falling into financial distress.

TABLE III. LEECO DEBT SOLVENCY DATA 2014-2018

\begin{tabular}{c|c|c|c|c|c}
\hline Year & $\mathbf{2 0 1 4}$ & $\mathbf{2 0 1 5}$ & $\mathbf{2 0 1 6}$ & $\mathbf{2 0 1 7}$ & $\mathbf{2 0 1 8}$ \\
\hline Liquidity ratio & 0.81 & 1.22 & 1.27 & 0.55 & 0.36 \\
\hline Quick ratio & 0.65 & 1.07 & 1.2 & 0.5 & 0.3 \\
\hline Asset-liability ratio & 0.62 & 0.78 & 0.67 & 1.04 & 1.41 \\
\hline $\begin{array}{c}\text { Interest coverage } \\
\text { ratio }\end{array}$ & 1.43 & 1.21 & 0.49 & -19.00 & -7.26 \\
\hline
\end{tabular}

In terms of short-term solvency, the liquidity ratio and quick ratio of LeEco show an inverted U-shaped trend of growth first and then decline with the boundaries of 2016. Before 2016, the liquidity ratio and the quick ratio both showed a rising trend, indicating that the short-term solvency of enterprises is increasing, and the liquidity of current assets is also increasing. However, since 2017, the two ratios have fallen sharply, and in 2018 they have fallen to about 0.3. Generally speaking, the current ratio of 2 is more appropriate, indicating that the current assets of enterprises are not enough to repay the current liabilities, and the operational risk is very high.

According to the annual report of 2018, the current liabilities of LeEco reached 8.133 billion RMB, but the amount of money on the books was only 538 million RMB. Even with the cash receivable of 0.06 billion totaling 544 million RMB, LeEco also faced a debt gap of 7.589 billion RMB. Thus, the short-term solvency of LeEco is very weak.

In terms of long-term solvency, the ratio of assets to liabilities of LeEco in the five years from 2014 to 2018 is higher than $50 \%$, and it almost shows a straight upward trend, and the debt burden of the company is increasing. In 2017 and 2018, LeEco's asset-liability ratio has exceeded $100 \%$, the company's asset structure is very dangerous, and the possibility of creditors recovering arrears is very low. Interest guarantee coefficient also shows a downward trend year by year. Enterprises are facing the risk of insolvency of debt and interest. This shows that the long-term solvency of enterprises is also worrying.

\section{Market value continued to decline}

Since November 2016, the rupture of the capital chain has caused a series of problems, such as collective requests from suppliers to repay their debts and successive departures of senior executives, which have had a great negative impact on LeEco. Since Nov. 2, 2016,LeEco shares continued to fall sharply, and lost more than 8 billion yuan in market value in the next two days, and then stopped after the next seven days, with a cumulative loss of tens of billion yuan. After the stock crash, stock prices continued to fall. On April 25, 2019, LeEco, which has been down for three consecutive days, opened its drop-off board with a turnover of 937 million yuan on that day, closing at 169 yuan per share and a total market value of 6.742 billion yuan. Compared with the company's stock price and market value reached the highest value of 179.03 yuan per share in the most glorious period of May 12, 2015, the total market value of the day was 150.5 billion yuan, which has shrunk by more than $95 \%$. On April 26, 2019, the company's annual report was published by LeEco, along with a risk warning announcement that the company's stock may be suspended from listing. The suspension of listing risk triggered by negative net assets has been suspended on the 26th of 2019 . The Shenzhen Stock Exchange will decide whether to suspend the listing of shares within 15 working days after the suspension. These threats will have a very negative impact on the company's sustainable development.

\section{ANALYSIS OF THE INFLUENCE OF MANAGERS'} OVERCONFIDENCE ON THE FINANCIAL DISTRESS OF LEECO

\section{A. The Impact of Investment Behavior on Financial Dilemma under Overconfidence of Managers}

\section{1) Analysis of Investment Situation}

Since listing, LeEco has been trying to build a "closed-loop ecological chain", whose business covers video, content, intelligent terminals, finance and many other fields. The rapid expansion of LeEco in many industries, especially terminal business LeEco Super TV and Super Mobile Phone, will inevitably lead to huge investment. In order to measure the cash flow status of investment activities of LeEco, this paper chooses Storm Player and Sohu Video, which belong to the network video service industry, as a comparison. Details are shown in Table 4:

TABLE IV. NET INVESTMENT OF LEECo (UNIT: 10,000 RMB)

\begin{tabular}{l|l|l|l|l|l}
\hline Year & $\mathbf{2 0 1 4}$ & $\mathbf{2 0 1 5}$ & $\mathbf{2 0 1 6}$ & $\mathbf{2 0 1 7}$ & $\mathbf{2 0 1 8}$ \\
\hline LeEco & $\begin{array}{l}152,567.7 \\
6\end{array}$ & $\begin{array}{l}298,475.0 \\
2\end{array}$ & $\begin{array}{l}967,537.9 \\
6\end{array}$ & $\begin{array}{l}194,983.8 \\
5\end{array}$ & $\begin{array}{l}5,465.0 \\
0\end{array}$ \\
\hline $\begin{array}{l}\text { Storm } \\
\text { Player }\end{array}$ & $6,839.34$ & $30,617.37$ & $47,206.37$ & $7,450.68$ & $\begin{array}{l}17,877 . \\
81\end{array}$ \\
\hline $\begin{array}{l}\text { Sohu } \\
\text { Video }\end{array}$ & $97,349.62$ & $35,784.93$ & $1,516.34$ & $9,130.53$ & $\begin{array}{l}33,850 . \\
16\end{array}$ \\
\hline
\end{tabular}

As can be seen from Table 4, except 2018, the investment level of LeEco is much higher than that of Storm Player and Sohu Video in the same industry. Overall, from 2014 to 2018, the trend of net investment of Storm Player and Sohu Video is relatively stable, while the net investment of LeEco has been growing rapidly in 2016 and before. Especially in 2016, when the net investment of LeEco reached the highest value of 9.675 billion yuan, it exceeded 9.303 billion yuan compared with Storm Player 's 472 million yuan and 9.660 billion yuan compared with Sohu's 515 million yuan, which shows that the investment of LeEco Network consumes a large amount of money and is obviously in the state of over-investment.

Until November 2016, the huge demand for funds caused by the excessive expansion of LeEco finally triggered the rupture of the capital chain, caused enterprises to bear huge debts, brought serious negative effects to enterprises, and the image of LeEco Star Company collapsed rapidly. With the rupture of the capital chain and the outbreak of financial crisis, 
investment of LeEco began to decline in 2017, but the net investment in 2017 is still much larger than that of Storm Player and Sohu Video. Combining the above analysis of financial distress, we can find that along with the rapid expansion of LeEco, its financial situation is deteriorating, resulting in the outbreak of financial crisis. Therefore, we can easily find that the outbreak of the company's financial crisis is closely related to its over-investment behavior.

2) The impact of managers' overconfidence on Financial Distress Based on investment behavior

According to the theory of overconfident "better than average" [ 7 ], overconfident managers believe that they have a high degree of professionalism. With rich management and decision-making experience, they can grasp the future direction of the company more accurately than ordinary employees, and better respond to opportunities and challenges. Jiang Fuxiu [ 8 thinks that when they make decisions, they often neglect the deviation between their subjective consciousness and objective facts, thus overestimating the investment returns and underestimating the potential risks of investment projects in the future, and making radical investment decisions.

LeEco has invested heavily driven by managers' overconfidence. In 2013, LeEco spent 1.598 billion yuan to buy $100 \%$ of Huaer Film and $99.5 \%$ of LeEco New Media; in 2014, LeEco Sports was established to enter the sports industry, and LeEco Mobile Communications Company was established to take charge of research and development and production of mobile phone projects; in 2015, it spent 1.875 billion yuan to subscribe 349 million new shares of TCL Multimedia. Faraday has invested a total of $\$ 1$ billion in building factories in the United States; in 2016, its shares and cash totaled 9.8 billion yuan to buy $100 \%$ of LeEco Film, invested 900 million yuan to increase its share of Cool Group to $28.90 \%$, and became its largest shareholder; in addition, LeEco has vigorously entered the real estate industry, with investment expenditure on domestic real estate approaching 66.7 billion yuan......

Because overconfident managers tend to overestimate returns and underestimate risks, they are more likely to make inefficient radical investment decisions. Under the overconfidence of managers, LeEco has been deployed in the fields of electronics, sports and terminals at the same time. Before a stable investment effect has been achieved in one field, it has begun to expand in other fields, which further leads to blind investment by enterprises. For example, the investment of terminal business such as TV and mobile phone has no advantage over professional manufacturers in production, $\mathrm{R} \& \mathrm{D}$ and sales. The cost of producing the same product is much higher than that of professional manufacturers. In addition, the gross profit margin of terminal business is very low because of the strategy of LeEco to expand market share by selling terminal products at low prices.

In addition, the company has invested a huge amount of money in research and development of LeEco cars, but it still needs to continue to invest funds to mass production and listing, that is, LeEco cars currently do not have a slight profit inflow, which undoubtedly lowers the company's profitability level. The company's layout in many areas occupies a large amount of funds, resulting in the company's investment in the main business video field decreased year by year. The timeliness of video requires continuous investment in new copyright content, and the increasing cost of copyright determines that the company's investment in video business should not be reduced. Therefore, in the long run, the video business of LeEco is also facing greater operational risks.

It can be seen that the investment decision-making driven by the over-confidence of LeEco managers does not enhance the profitability of enterprises, but makes enterprises face greater risks. The potential risks of each project overlap with each other, which eventually leads to the breakdown of the fund chain and financial difficulties of LeEco.

\section{B. The Impact of Financing Behavior on Financial Dilemma under Overconfidence of Managers}

\section{1) Analysis of Financing Situation}

The large amount of money spent to "capture territory" by LeEco directly leads to the net outflow of investment cash of the company since 2013, which cannot effectively supplement the monetary funds. In addition, the company's profitability is deteriorating, and its profit level is declining. The company itself has limited hematopoietic capacity. Therefore, LeEco relies heavily on financing activities to raise funds to meet the needs of the company's normal business activities and investment expenditure. This section still chooses Storm Player and Sohu Video, which belong to the network video service industry, as a comparison to measure the financing status of LeEco.

TABLE V. LE VIDEO NETWORK ASSET-Liability RATIO STATEMENT

\begin{tabular}{c|c|c|c|c|c}
\hline Year & $\mathbf{2 0 1 4}$ & $\mathbf{2 0 1 5}$ & $\mathbf{2 0 1 6}$ & $\mathbf{2 0 1 7}$ & $\mathbf{2 0 1 8}$ \\
\hline LeEco & $62.63 \%$ & $77.53 \%$ & $67.48 \%$ & $103.72 \%$ & $141.25 \%$ \\
\hline Storm Player & $36.21 \%$ & $50.62 \%$ & $67.69 \%$ & $68.86 \%$ & $168.69 \%$ \\
\hline Sohu Video & $41.09 \%$ & $43.12 \%$ & $39.24 \%$ & $46.36 \%$ & $52.92 \%$ \\
\hline
\end{tabular}

Asset-liability ratio is the ratio of total liabilities to total assets. It reflects how much of the total assets of an enterprise is obtained by borrowing. As can be seen from Table 5, except 2018, the asset-liability ratio of LeEco is higher than that of Storm Player and Sohu Video in the same industry, and it is increasing substantially every year. The Storm Player is called a simplified version of the LeEco imitator by the industry. Its "ecosphere strategy" is similar to LeEco in that it involves three major sectors: content, platform and data. Therefore, it relies heavily on financing to achieve its own industrial layout. This is also the reason why the asset-liability ratio of Storm Player is increasing year by year, even up to $168.69 \%$ in 2018 . Today's Storm Player are also in a situation of constant losses, falling stock prices and crises.

It is generally believed that the ratio of assets to liabilities should not exceed $60 \%$. If the ratio is too high, enterprises will face great financial risks. However, from 2014 onwards, it has been higher than $60 \%$, which shows that more than half of the company's assets come from debt and face great financial risks. In 2017 and 2018, the ratio of assets to liabilities even exceeded $100 \%$, indicating that the company is insolvent and 
its net assets are negative, which makes the company face the risk of delisting. All these indicate that LeEco is in a state of over-indebtedness. Once the capital chain breaks down, the company can easily get into financial difficulties.

2) The influence of managers' overconfidence based on financing behavior on financial distress

Enterprise financing can be divided into internal financing and external financing. Internal financing of enterprises is the capital source formed by internal retained profits, which is formed naturally within the enterprise. The amount of internal financing is usually determined by the size of the enterprise's distributable profits and the policy of profit distribution. As can be seen from the above, the profitability of LeEco is declining continuously, and the net profit of LeEco is also declining seriously every year. Therefore, the level of internal financing of LeEco is limited, so debt and equity financing are its main financing methods.

TABLE VI. STATISTICS TABLE OF FUNDRAISING OF LEECO (UNIT: 10,000 $\mathrm{RMB})$

\begin{tabular}{|c|c|c|c|c|c|}
\hline year & 2014 & 2015 & 2016 & 2017 & 2018 \\
\hline \multicolumn{6}{|l|}{ New Loans } \\
\hline & $\begin{array}{l}266,060 . \\
00\end{array}$ & $\begin{array}{l}904,657 . \\
44\end{array}$ & $\begin{array}{l}628,956.2 \\
7\end{array}$ & $\begin{array}{l}374,620 . \\
05\end{array}$ & $\begin{array}{l}81,277 . \\
50\end{array}$ \\
\hline \multicolumn{6}{|l|}{ Issuance of shares } \\
\hline & $\begin{array}{l}42,039.7 \\
5\end{array}$ & $4,791.03$ & $\begin{array}{l}1,114,451 . \\
32\end{array}$ & $\begin{array}{l}315,764 . \\
99\end{array}$ & $\begin{array}{l}73,000 . \\
00\end{array}$ \\
\hline $\begin{array}{l}\text { Net cash flow } \\
\text { from fund-raising } \\
\text { activities }\end{array}$ & $\begin{array}{l}115,326 . \\
70\end{array}$ & $\begin{array}{l}436,534 . \\
91\end{array}$ & $\begin{array}{l}947,749.9 \\
8\end{array}$ & $\begin{array}{l}385,360 . \\
32\end{array}$ & $\begin{array}{l}86,377 . \\
92\end{array}$ \\
\hline
\end{tabular}

For external financing, overconfident managers have high expectations of future earnings, and equity financing will dilute their own shares. In order to avoid dilution of profits, managers will be more inclined to debt financing. From Table 6 above, we can find that LeEco preferred debt financing until it was exposed that the capital chain was broken in 2016. The capital inflow from borrowing was much higher than that from issuing shares. Especially in the trend of increasing new loans year by year from 2014 to 2015, the amount of funds raised by issuing shares was declining year by year. It further demonstrates the overconfidence of the network managers and their optimism for the development model of "closed-loop ecological chain" of enterprises. It is believed that this model can bring rich profit returns to enterprises. Therefore, in order to avoid the decrease of their income, the management of LeEco is more and more inclined to debt financing.

However, due to the excessive self-confidence of managers, when building a closed-loop vertical integration framework of "platform + content + terminal + application", in order to meet the needs of large amounts of funds in various business areas, enterprises continue to expand the scale of financing to achieve the expansion of LeEco 's ecological strategy. And the increasing trend of LeEco 's fund-raising scale is the most obvious between 2014 and 2015, the largest fund-raising scale is 9.475 billion yuan in 2016. In fact, the large investment of LeEco in many business areas (such as terminal business) did not achieve the expected revenue, but reduced the overall profitability of the company. When the money invested by enterprises is longer than the money coming in, liquidity becomes a hidden danger, which leads to the shortage of funds. Therefore, enterprises will rely more on external investment. From the analysis of Table 5, we can see that LeEco 's liabilities are at a high level, which makes enterprises face great financial risks and more likely to face financial difficulties. After 2016, the scale of enterprise financing has been declining, which shows that the difficulty of enterprise refinancing has increased and the enterprise operation is facing difficulties.

In addition, although equity investment can ensure that managers' equity is not diluted, debt financing generally has a fixed interest burden and repayment period, so debt financing will increase financing costs and debt repayment pressure.

TABLE VII. LEECo FinANCIAL EXPENSES STATISTICS TABLE (UNIT: $10,000 \mathrm{RMB})$

\begin{tabular}{|c|c|c|c|c|c|}
\hline Year & 2014 年 & 2015 年 & 2016 年 & 2017 年 & 2018 年 \\
\hline LeEco & $16,800.00$ & $34,900.00$ & $64,800.00$ & $87,300.00$ & $\begin{array}{l}68,700.0 \\
0\end{array}$ \\
\hline $\begin{array}{l}\text { Storm } \\
\text { Player } \\
\end{array}$ & -21.29 & -205.99 & $2,603.43$ & $4,034.85$ & $\begin{array}{l}12,300.0 \\
0\end{array}$ \\
\hline Sohu Video & $\begin{array}{l}- \\
18,954.83 \\
\end{array}$ & $\begin{array}{l}- \\
15,233.34 \\
\end{array}$ & $\begin{array}{l}- \\
14,104.71\end{array}$ & $\begin{array}{l}- \\
13,057.56 \\
\end{array}$ & - \\
\hline
\end{tabular}

The excessive self-confidence of the managers of LeEco makes the proportion of debt financing in the scale of financing increase continuously, which leads to the rising financing cost of LeEco. As shown in Tables 6 and 7, when the financial costs of Storm Player and Sohu video in the same industry are in a relatively stable and low lever from 2014 to 2018, the financial costs of LeEco have been on the rising trend until 2017, and are larger than those of Storm Player and Sohu video. In 2014, the financial cost of LeEco was only 118 million, while in 2017 it reached the highest value, breaking through 800 million. The financial cost of Storm Group was only 123 million in 2018, and the financing cost of Sohu Video was the smallest. Even from 2014 to 2018 , it had been in the state of positive net interest cost and inflow of net interest income. It can be seen that the financing cost of LeEco is high. High financing costs have seriously reduced the business profits of enterprises, and also led to a decline in the refinancing capacity of enterprises. Once the capital chain breaks, enterprises will be unable to repay the principal and interest into financial difficulties. And after the large amount of debt, it is precisely because of the break of the capital chain, leading to stock prices fell sharply, many times suspended, and getting into financial difficulties.

\section{CONCLUSION AND DISCUSSION}

This paper analyses the adverse effects of Managerial Overconfidence on financial distress from two kinds of behavior intermediaries: investment and financing. The following conclusions are drawn:

\section{a) In terms of investment:}

the over-confidence of the managers of LeEco exerts a subtle influence on the company's investment decision-making behavior. Overconfidence leads them to overestimate the investment returns that investment projects may bring in the 
future, and underestimate the potential risks, which leads to overinvestment. However, due to the large expansion pace, the resource distribution of enterprises is too decentralized to meet the capital needs of all business areas, seriously affecting the profitability of enterprises. It can be seen that the blind investment behavior caused by managers' overconfidence has not injected endless vitality into the enterprise, which makes the enterprise have enough hematopoietic capacity. On the contrary, the investment efficiency is getting lower and lower, which accelerates the deterioration of the financial situation of the enterprise and leads to the financial distress of the enterprise.

\section{b) In terms of financing:}

combined with the theory of orderly financing, overconfident managers have high expectations of future earnings when facing the financing needs of enterprises. In order to avoid the dilution of profits, they choose more debt financing methods, and the proportion of debt financing is increasing. However, the high level of asset-liability ratio leads to high financing costs, which further reduces the operating profits of enterprises, makes enterprises face great financial risks, and then step by step into financial difficulties.

Managers' over-confidence, which is mediated by investment and financing behavior, has a negative impact on the financial situation of LeEco, and eventually leads to financial difficulties of enterprises. In view of the fact that managers' overconfidence will lead to financial distress of enterprises, this paper puts forward the following suggestions:

a) Managers should study constantly and reflect actively:

Managers are generally professionals with high educational background and rich business experience. Therefore, overconfidence is common among business managers, but most of the time managers do not have a clear understanding of the psychological state between them. Therefore, enterprises can regularly conduct training, seminars or lectures to help managers have a clearer understanding of behavioral finance, overconfidence and other related theories. With the guidance of theory to practice, managers can better recognize themselves and avoid the negative impact of their overconfidence on the company's strategic decision-making. In addition, managers themselves should take the initiative to learn relevant knowledge, reflect on and revise their relevant decisions in learning.

b) Optimizing the corporate governance and supervision structure:

Enterprises should strive to continuously improve the corporate governance and supervision mechanism. By combining the internal and external governance structure of the company, we can promote the mutual restriction and coordination among stakeholders. In addition, a good supervision mechanism is conducive to better and faster correcting deviations in the management and decision-making process of enterprises. For LeEco, if an enterprise can consider its involvement in other fields after a stable business has achieved certain results, it will largely avoid the overinvestment of the enterprise. Therefore, it is of great significance to optimize the corporate governance and supervision structure and restrain the irrational decisionmaking of managers.

c) Establishing and perfecting the restriction and incentive mechanism of enterprises:

Enterprises should establish relevant restraint and incentive mechanisms to restrict managers' overconfident behavior and unreasonable strategic decisions driven by overconfidence. For example, enterprises can increase the review of managers' personality characteristics in the appointment mechanism of managers. In the establishment of compensation mechanism, besides the profit as an evaluation index, it should also combine the assessment of the rationality of the capital structure and financing scale of the company. Because of the overconfidence of the managers, LeEco has a high capitalliability ratio. Without fully measuring the profitability of enterprises, it blindly enlarges the scale of debt financing, which further aggravates the financial distress of enterprises. Therefore, the establishment and improvement of enterprise restraint and incentive mechanism is conducive to reducing managers' overconfidence and preventing financial distress.

\section{REFERENCES}

[1] Roll, Richard. The Hubris Hypothesis of Corporate Takeovers. Journal of Business. 1986, (59)197-216.

[2] Yu Minggui, Xia Xinping, Zou Zhensong. Managerial Overconfidence and Corporate Radical Debt Behavior. Managing the World, 2006 (8): 104-172

[3] Oliver. Structure the Impact of Management Confidence on Capital Australian National University. working paper. 2005.

[4] Malmendier and Tate. CEO Overconfidence and Corporate Investment [J]. Journal of Finance,2005(12): 2661-2700.

[5] Doukas,John A,Dimitris Petmezas. Acquisitions, Overconfident Managers and Self-Attribution Bias. European Financial Management Association, 2006.

[6] Yu Sujing. * Case analysis of ST Long Oil Expansion failure based on the perspective of managerial overconfidence. Zhejiang University of Finance and Economics, 2017

[7] Larwood L, Whittaker W. Managerial myopia:self-serving biases in organizational planning. Journal of Applied Psychology, 1977, 62( 2) : 194-198.

[8] Jiang Fuxiu, Zhang Min, Lu Zhengfei and others. Overconfidence of managers, enterprise expansion and financial distress. Economic Research, 2009 (1): 131-143. 